\title{
MicroRNA and its Potential Use for the Treatment of Hepatitis C Virus Infection
}

\author{
Wendi Zhao ${ }^{1}$, Xiaoqiong Duan², Yujia $\mathrm{Li}^{2}$, Shilin $\mathrm{Li}^{2}$, Bing Liu ${ }^{2}$ and Limin Chen ${ }^{2,3 *}$ \\ ${ }^{1}$ West China Hospital, Sichuan University, Chengdu, Sichuan, 610041 China \\ ${ }^{2}$ Institute of Blood Transfusion (IBT), Chinese Academy of Medical Sciences and Peking Union Medical College, Chengdu, Sichuan 610052 China \\ ${ }^{3}$ Toronto General Research Institute, University of Toronto, Toronto, ON M5G 1L6, Canada
}

\section{Hepatitis C Virus and Treatment Regimen}

Hepatitis $\mathrm{C}$ virus (HCV) is a world-wide health problem with about 150 million people (3\% of the world population) (www.who. int) chronically infected. HCV is a single, positive-strand RNA virus that belongs to Flaviviridae family [1]. The full length of HCV genome contains $9.6 \mathrm{~kb}$ and encodes a polyprotein precursor of about 3000 amino acids that is then cleaved by host and viral proteases into three structural proteins (core, E1, and E2) and seven nonstructural proteins (p7, NS2, NS3, NS4A, NS4B, NS5A, and NS5B) $[2,3]$.

Chronic HCV infection frequently results in progressive inflammation, fibrosis, cirrhosis, and an increased risk of hepatocellular carcinoma [4]. There are 6 major genotypes of HCV and genotype 1 is the most prevalent in many countries and also is the hardest to treat [5-9]. Standard treatment for HCV infection involves a combination therapy with pegylated interferon alpha (IFN) and ribavirin (RBV). However, only $40-50 \%$ patients infected with HCV genotype 1 and $80 \%$ in patients infected with HCV genotypes 2 or 3 achieve a sustained virologic response (SVR) [10,11]. Most recently, a direct acting antiviral agent (DAA)-based "triple therapy", combining a HCV NS3/4A protease inhibitor with IFN/RBV, has been proposed to be the standard-of-care for genotype 1 infection and this triple therapy improved the SVR up to $75 \%[9,12]$. Two NS3/4A protease inhibitors, Telaprevir and Boceprevir, have been approved by the Food and Drug Administration (FDA) [13] Although the adoption of triple therapy has improved response rates, the high cost, drug-drug interactions and severe side effects limit its use, especially in many developing countries where the treatment need most $[13,14]$. Therefore, it is necessary to explore other treatment options.

\section{MicroRNAs and their Mimics or Anti-microRNAs}

MicroRNAs (miRNAs) are small non-coding RNAs that regulate gene expression after transcription [15-18]. Mature miRNAs are transcribed from introns and exons of protein-coding genes or intergenic regions [19]. Transcription of miRNA genes forms primary transcripts (pri-miRNAs) that usually contain a hairpin structure consisting of a double-stranded stem and a terminal loop [20]. The stem-loop structure is then cleaved by an RNaseIII-like enzyme called drosha, together with its binding partner DGCR8 (DiGeorge syndrome critical region 8 ), to produce a $\sim 70 \mathrm{nt}$ precursor miRNA (pre-miRNA) [14,21-23]. The pre-miRNA is then transferred from the nucleus to the cytoplasm with the help of exportin-5 and its co-factor Ran-GTP (GTP bound form of cofactor Ras-related nuclear protein), where it is processed into a duplex structure by RNA polymerase III dicer [24]. Subsequently, one strand named "guide strand" binds to an Argonaute protein and is integrated into an RISC (RNA-induced silencing complex) that recognizes and binds to the target mRNA; the other strand is degraded and nonfunctional $[15,25]$. The binding of miRNA and its target results in degradation of the target mRNA or suppression of mRNA translation [26,27].
More than 1500 miRNAs (www.mirbase.org, released January 2012) have been identified in human genome and they are involved in almost every cell process, including development, differentiation, proliferation, death, disease pathology, and antiviral defence [2831]. As a major host factor, miRNA represents an interesting field for studying the host-HCV interaction, ranging from HCV infection to the new targets for antiviral therapy [32]. In recent years, some oligonucleotide compounds were designed to mimic or sequester miRNAs as potential drug candidates and achieved promising results. For the miRNA mimic, the "guide strand" is identical to the interested miRNA and the "nonfunction strand" is modified and typically linked to a molecule such as cholesterol for enhanced cellular uptake [33]. Anti-miRs are modified antisense oligonucleotides harboring the full or partial complementary reverse sequence of a mature miRNA that can reduce the endogenous levels of an miRNA [33]. Two approaches to produce anti-miRs have been reported: one is 2-O-methyl-group (OMe)-modified oligonucleotides and the other is locked nucleic acid (LNA)-modified oligonucleotides [34,35].

In this review, we will focus on miRNAs that have been shown to have promising therapeutic effect for the treatment of HCV infection.

\section{Treatment of HCV by $\mathrm{T}$ targeting miR-122}

Of all the human miRNAs, miR-122 is one of the most studied. As a liver-specific and the most abundant miRNA ( $70 \%$ of the liver total miRNAs), miR-122 plays a pivotal role in regulating hepatic functions [36]. Previous studies demonstrated that miR-122 is essential for HCV replication, which makes it an attractive host target for anti-HCV therapy [37]. miR-122 protects HCV from host immune attack by binding to two adjacent target sites in 5 ' untranslated region (5 'UTR) of HCV RNA [38,39]. Miravirsen (SPC3649, Santaris Pharma, Hørsholm, Denmark), an anti-miR-122 agent complementary to miR-122, has been shown to have significant anti-HCV activity both in animal model and Phase I and IIa studies [40-42]. Treatment of HCV chronically infected chimpanzees with a LNA-modified oligonucleotide (SPC3649) achieved a prolonged and marked suppression of HCV viremia with no evidence for viral resistance or side effects in the treated animals [41]. Most recently, a randomized, doubleblind, placebo-controlled,

*Corresponding author: Limin Chen, Toronto General Research Institute, University of Toronto, Toronto, ON M5G 1L6, Canada, Tel: 86-28-66430656; E-mail: limin_chen_99@yahoo.com, limin.chen@utoronto.ca

Received February 28, 2014; Accepted March 04, 2014; Published March 08 2014

Citation: Zhao W, Duan X, Li Y, Li S, Liu B, et al. (2014) MicroRNA and its Potential Use for the Treatment of Hepatitis C Virus Infection. J Bioanal Biomed 6: e125. doi:10.4172/1948-593X.1000e125

Copyright: $\odot 2014$ Zhao W, et al. This is an open-access article distributed under the terms of the Creative Commons Attribution License, which permits unrestricted use, distribution, and reproduction in any medium, provided the original author and source are credited. 
Citation: Zhao W, Duan X, Li Y, Li S, Liu B, et al. (2014) MicroRNA and its Potential Use for the Treatment of Hepatitis C Virus Infection. J Bioanal Biomed 6: e125. doi:10.4172/1948-593X.1000e125

Page 2 of 3

ascending multiple dose-ranging Phase IIa study was finished in patients with chronic HCV genotype 1 infection [42]. The results showed that four-week injection of miravirsen provided significantly dose-dependent anti-HCV activity with a mean reduction of 2 to $3 \operatorname{logs}$ from baseline in HCV RNA and 5 patients even had an undetectable HCV RNA levels after the treatment period [42]. However, considering miR-122 is an important host cellular factor involving in hepatocytes metabolism, although current data from the clinical study was promising, further investigation with long period of treatment and large sample size are needed to further clarify these concerns $[32,43]$.

\section{Other miRNAs that have Potential Use for the Treatment of HCV Infection}

Besides miR-122, many other miRNAs were identified to be involved in HCV replication and infection. Similar to miR-122, miR-196 and miR-199a were reported to have direct interaction with HCV RNA by binding to NS5A-coding region and 5'UTR IRES respectively, which make them the most promising therapeutic targets [44,45]. miR-130a was reported to regulate HCV replication in vitro $[46,47]$. Chowdhury et al. identified IFITM1, which can inhibit HCV replication, as a potential miR-130a target [46]. From this study, it is reasonable to conclude that miR-130a is a positive regulator for $\mathrm{HCV}$ replication. However, most recently, $\mathrm{Li}$ et al found that the replication of HCV RNA was significantly decreased after overexpression of miR130a both in HCV replicon cells and J6/JFH HCV culture system [47]. These seemingly contradictory findings implied the complicated interaction between miR-130a and HCV and miR-130a as the potential target for HCV treatment. Although all these miRNAs are promising targets for HCV treatments, further studies are needed to uncover their cellular targets and their mechanism of action.

\section{Future Directions}

The advent of anti-miR-122 drugs is opening an exciting new era for hepatitis $\mathrm{C}$ treatment although more comprehensive and long-time effects should be pursued. Many other miRNAs have been reported to regulate $\mathrm{HCV}$ replication and they have great potential as therapeutic targets for HCV infection.

\section{References}

1. Shrivastava S, Mukherjee A, Ray RB (2013) Hepatitis C virus infection, microRNA and liver disease progression. World J Hepatol 5: 479-486.

2. Georgel P, Schuster C, Zeisel MB, Stoll-Keller F, Berg T, et al. (2010) Virushost interactions in hepatitis $\mathrm{C}$ virus infection: implications for molecular pathogenesis and antiviral strategies. Trends Mol Med 16: 277-286.

3. Rice CM (2011) New insights into HCV replication: potential antiviral targets. Top Antivir Med 19: 117-120.

4. Kim CW, Chang KM (2013) Hepatitis C virus: virology and life cycle. Clin Mo Hepatol 19: 17-25.

5. Nainan OV, Alter MJ, Kruszon-Moran D, Gao FX, Xia G, et al. (2006) Hepatitis C virus genotypes and viral concentrations in participants of a general population survey in the United States. Gastroenterology 131: 478-484.

6. Rustgi VK (2007) The epidemiology of hepatitis C infection in the United States. J Gastroenterol 42: 513-521.

7. Dusheiko G, Schmilovitz-Weiss H, Brown D, McOmish F, Yap PL, et al. (1994) Hepatitis $C$ virus genotypes: an investigation of type-specific differences in geographic origin and disease. Hepatology 19: 13-18.

8. Nousbaum JB, Pol S, Nalpas B, Landais P, Berthelot $P$, et al. (1995) Hepatitis C virus type $1 \mathrm{~b}$ (II) infection in France and Italy. Collaborative Study Group. Ann Intern Med 122: 161-168.

9. Ghany MG, Nelson DR, Strader DB, Thomas DL, Seeff LB; American
Association for Study of Liver Diseases (2011) An update on treatment of genotype 1 chronic hepatitis $C$ virus infection: 2011 practice guideline by the American Association for the Study of Liver Diseases. Hepatology 54: 14331444.

10. Fried MW, Shiffman ML, Reddy KR, Smith C, Marinos G, et al. (2002) Peginterferon alfa-2a plus ribavirin for chronic hepatitis $C$ virus infection. N Engl J Med 347: 975-982.

11. Hadziyannis SJ, Sette H, Morgan TR, Balan V, Diago M et al. (2004) Peginterferon-alpha2a and ribavirin combination therapy in chronic hepatitis $\mathrm{C}$ a randomized study of treatment duration and ribavirin dose. Ann Intern Med 140: 346-355

12. Bühler S, Bartenschlager R (2012) New targets for antiviral therapy of chronic hepatitis C. Liver Int 32 Suppl 1: 9-16.

13. Casey LC, Lee WM (2013) Hepatitis C virus therapy update 2013. Curr Opin Gastroenterol 29: 243-249.

14. Duan XQ, Li SL, Li YJ, Zeng PB, Yang CH, et al. The Role of MicroRNA in Hepatitis C Virus Replication Alternate Title: MicroRNA in HCV Replication. Journal of Clinical and Translational Hepatology 1: 125-130.

15. Kim VN (2005) MicroRNA biogenesis: coordinated cropping and dicing. Nat Rev Mol Cell Biol 6: 376-385

16. Tomari Y, Zamore PD (2005) Perspective: machines for RNAi. Genes Dev 19: 517-529.

17. Lagos-Quintana M, Rauhut R, Lendeckel W, Tuschl T (2001) Identification of novel genes coding for small expressed RNAs. Science 294: 853-858.

18. Ambros V, Bartel B, Bartel DP, Burge CB, Carrington JC, et al. (2003) A uniform system for microRNA annotation. RNA 9: 277-279.

19. Kim VN, Nam JW (2006) Genomics of microRNA. Trends Genet 22: 165-173.

20. Slezak-Prochazka 11, Durmus S, Kroesen BJ, van den Berg A (2010) MicroRNAs, macrocontrol: regulation of miRNA processing. RNA 16: 10871095.

21. Denli AM, Tops BB, Plasterk RH, Ketting RF, Hannon GJ (2004) Processing of primary microRNAs by the Microprocessor complex. Nature 432: 231-235.

22. Lee $\mathrm{Y}$, Ahn C, Han J, Choi H, Kim J, et al. (2003) The nuclear RNase III Drosha initiates microRNA processing. Nature 425: 415-419.

23. Gregory RI, Yan KP, Amuthan G, Chendrimada T, Doratotaj B, et al. (2004) The Microprocessor complex mediates the genesis of microRNAs. Nature 432 235-240.

24. Yi R, Qin Y, Macara IG, Cullen BR (2003) Exportin-5 mediates the nuclea export of pre-microRNAs and short hairpin RNAs. Genes Dev 17: 3011-3016.

25. Bartel DP (2004) MicroRNAs: genomics, biogenesis, mechanism, and function Cell 116: 281-297.

26. Eulalio A, Huntzinger E, Izaurralde E (2008) Getting to the root of miRNAmediated gene silencing. Cell 132: 9-14.

27. Filipowicz W, Bhattacharyya SN, Sonenberg N (2008) Mechanisms of posttranscriptional regulation by microRNAs: are the answers in sight? Nat Rev Genet 9: 102-114.

28. Stefani G, Slack FJ (2008) Small non-coding RNAs in animal development. Nat Rev Mol Cell Biol 9: 219-230.

29. Foshay KM, Gallicano GI (2007) Small RNAs, big potential: the role of MicroRNAs in stem cell function. Curr Stem Cell Res Ther 2: 264-271.

30. Blakaj A, Lin $H$ (2008) Piecing together the mosaic of early mammalian development through microRNAs. J Biol Chem 283: 9505-9508.

31. Zhou R, O'Hara SP, Chen XM (2011) MicroRNA regulation of innate immune responses in epithelial cells. Cell Mol Immunol 8: 371-379.

32. Hoffmann TW, Duverlie G, Bengrine A (2012) MicroRNAs and hepatitis C virus: toward the end of miR-122 supremacy. Virol J 9: 109.

33. van Rooij E, Purcell AL, Levin AA (2012) Developing microRNA therapeutics. Circ Res 110: 496-507.

34. Krützfeldt J, Kuwajima S, Braich R, Rajeev KG, Pena J, et al. (2007) Specificity, duplex degradation and subcellular localization of antagomirs. Nucleic Acids Res 35: 2885-2892. 
Citation: Zhao W, Duan X, Li Y, Li S, Liu B, et al. (2014) MicroRNA and its Potential Use for the Treatment of Hepatitis C Virus Infection. J Bioanal Biomed 6: e125. doi:10.4172/1948-593X.1000e125

Page 3 of 3

35. van Rooij E (2011) The art of microRNA research. Circ Res 108: 219-234.

36. Lagos-Quintana M, Rauhut R, Yalcin A, Meyer J, Lendeckel W, et al. (2002) Identification of tissue-specific microRNAs from mouse. Curr Biol 12: 735-739.

37. Jopling CL, Yi M, Lancaster AM, Lemon SM, Sarnow P (2005) Modulation of hepatitis C virus RNA abundance by a liver-specific MicroRNA. Science 309: 1577-1581.

38. Machlin ES, Sarnow P, Sagan SM (2011) Masking the 5' terminal nucleotides of the hepatitis $C$ virus genome by an unconventional microRNA-target RNA complex. Proc Natl Acad Sci U S A 108: 3193-3198.

39. Shimakami T, Yamane D, Jangra RK, Kempf BJ, Spaniel C, et al. (2012) Stabilization of hepatitis C virus RNA by an Ago2-miR-122 complex. Proc Natl Acad Sci U S A 109: 941-946.

40. Hildebrandt-Eriksen ES, Bagger YZ, Knudsen TB, Petri A, Persson R, et al (2009) A unique therapy for HCV inhibits microRNA-122 in humans and results in HCV RNA suppression in chronically infected chimpanzees: results from primate and first-in-human studies. In: Hepatology, JOHN WILEY \& SONS INC, Newzland, USA 12A-12A.

41. Lanford RE, Hildebrandt-Eriksen ES, Petri A, Persson R, Lindow M, et al. (2010)
Therapeutic silencing of microRNA-122 in primates with chronic hepatitis C virus infection. Science 327: 198-201.

42. Janssen HL, Reesink HW, Lawitz EJ, Zeuzem S, Rodriguez-Torres M, et al (2013) Treatment of HCV infection by targeting microRNA. N Engl J Med 368 : 1685-1694.

43. Jopling C (2012) Liver-specific microRNA-122: Biogenesis and function. RNA Biol 9: 137-142.

44. Pedersen IM, Cheng G, Wieland S, Volinia S, Croce CM, et al. (2007) Interferon modulation of cellular microRNAs as an antiviral mechanism. Nature 449: 919922.

45. Murakami Y, Aly HH, Tajima A, Inoue I, Shimotohno K (2009) Regulation of the hepatitis $C$ virus genome replication by miR-199a. J Hepatol 50: 453-460.

46. Bhanja Chowdhury J, Shrivastava S, Steele R, Di Bisceglie AM, Ray R, et al. (2012) Hepatitis $C$ virus infection modulates expression of interferon stimulatory gene IFITM1 by upregulating miR-130A. J Virol 86: 10221-10225.

47. Li S, Duan X, Li Y, Liu B, McGilvray I, et al. (2014) MicroRNA-130a inhibits HCV replication by restoring the innate immune response. J Viral Hepat 21: 121-128. 